\title{
THE GRAUTHERMIC-TYRES PROCESS FOR THE RECYCLING OF GRANULATED SCRAP TYRES
}

Félix A. López ${ }^{1, *}$, Teresa A. Centeno ${ }^{2}$, Francisco J. Alguacil ${ }^{1}$, Belén Lobato ${ }^{2}$ and Andrea Urien ${ }^{1}$

${ }^{1}$ Centro Nacional de Investigaciones Metalúrgicas (CENIM), CSIC, Avda. Gregorio del Amo 8, 28040 Madrid, Spain.

2 Instituto Nacional del Carbón (INCAR), CSIC, Apartado 73, 33080 Oviedo, Spain.

\begin{abstract}
The influence of thermolysis temperature (range $500-700^{\circ} \mathrm{C}$ ) on the products produced from granulated scrap tyres (GST) $(2-6 \mathrm{~mm} \varnothing)$ in a semi-batch pilot plant that uses several fixed bed reactors in parallel (GRAUTHERMIC-Tyres ${ }^{\circledR}$ process) was examined. This pilot unit consisted of six vertical fixed bed reactors in parallel, each with a capacity of $12 \mathrm{~kg}$ GST. Thermolysis proceeded in a normal air atmosphere. The solid (char), liquid (tyre-derived oil [TDO]) and gaseous products generated at each temperature were characterised. The incondensable gas fraction was used to produce electricity via a gas turbine. The yields of the gas, TDO and char fractions were 15-22 wt.\%, 34-46 wt.\% and 39-44 wt.\% respectively, values that represent major recoveries from the GST feedstock. The TDOs were mainly a mixture of aliphatic and aromatic hydrocarbons and had very high GCVs (41-43 MJ/kg), higher than those of conventional liquid fuels. A large increase was seen in the polycyclic aromatic hydrocarbon content above $550^{\circ} \mathrm{C}$. The non-condensable gases obtained had a high GCV value (64-83 $\mathrm{MJ} / \mathrm{Nm}^{3}$ ), and produced 4.1-6.5 $\mathrm{kWh}$ electricity $/ \mathrm{g}$ of GST in a gas turbine. The chars had a GCV of 27-28 MJ/kg, high ash (17-21 wt.\%) and zinc contents, and an essentially macroporous texture with a low BET surface area $\left(46-78 \mathrm{~m}^{2} / \mathrm{g}\right)$. The thermolysis of GSTs with co-generation of gases by the GRAUTHERMIC-Tyres ${ }^{\circledR}$ method would appear to be a viable means of valorising GST.
\end{abstract}

Keywords: Granulated Scrap Tyres; Thermolysis; Recycling, Tyre-derived-oil; Char

* Corresponding author.

E-mail address: flopez@cenim.csic.es (F. A. López) 


\section{Introduction}

Some 1000 million end-of-life tyres (ELTs) - around 13.5 Mt, a figure that could rise to over $17 \mathrm{Mt}$ [1] - have to be disposed of each year. In industrialised countries, around 37\% of these ELTs are energetically valorised (usually in cement ovens), 23\% are treated mechanically to recover useful materials, $27 \%$ are retreaded, and $17 \%$ end up in landfills, (though this is declining) [2].

Over the last two years, numerous scrap tyre granulation plants have been installed in Europe. In Spain alone, there are 13, with a treatment capacity of 100,000 t/year, producing some 65,000 t/year of largely steel- and fluff-free granulated. Their granulated product is classified into three sizes. The $<0.8 \mathrm{~mm}$ fraction is used in the manufacture of asphalt, although the market for this is small, and the $0.8-2 \mathrm{~mm}$ fraction is used in the production of artificial sports turf, a market now suffering from public spending cuts. Unfortunately, there is virtually no market for the $2-12 \mathrm{~mm}$ fraction. The result is an excess production of some $60,000 \mathrm{t} / \mathrm{year}$ of these granulated products. Their energetic revalorisation is therefore of great interest.

A number of authors have investigated the pyrolysis of waste tyres at the laboratory and industrial scale, in both inert and partially oxidizing atmospheres, using fixed bed reactors [3, 4], rotary kilns [5, 6], circulating fluid beds [7], bubbling fluid beds [8], vacuum moving beds [9] and incineration/combustion reactors [10-12], in co-combustion with coal or other fuels [13], in gasification systems [14], and in conical spouted bed reactors [15]. More recent research trends have involved thermal plasma pyrolysis, pyrolysis in the presence of catalysts (zeolites) [16], and hydrogenerative pyrolysis [17-18]. The economic viability of the pyrolytic treatment of ELTs depends largely on the quantities and properties of the gases, tyre-derived oil (TDO) and char formed. Many industrial initiatives have failed because of the lack of markets for these products, or the low profitability of the process.

Tyre-derived oils have gross calorific values (GCV) of around $41-44 \mathrm{MJ} / \mathrm{kg}$, similar to those of commercial heating oils [19-20]. They can be used as such, although in most European Union countries this is strictly regulated. In Spain, for example, they must comply with the technical specifications [21] of Standard ISO 4259 [22] for use as automotive (class A), agricultural or maritime (class B) or heating (class C) fuels. In some countries, legislation allows these oils to be mixed with fuel oil in proportions of up to $10 \mathrm{vol} \%$ [23]. TDOs are also a potential source of benzene, toluene and xylene (BTX) and limonene [24].

The pyrolytic chars produced from granulated scrap types (GST; 30-40 wt.\% of the initial feedstock) have a moderate energy potential (30-40 MJ/kg). Some have physical and textural characteristics similar to certain commercial carbon blacks, but their high ash (12-16 
wt.\%), sulphur (1.8- $4 \mathrm{wt} \%$ ) and zinc (3-5 wt.\%) contents hinder their re-use in the tyre industry. Acidic demineralisation [25-26] and physical and chemical activation [27-28] can improve their chemical and physical properties, but these steps are costly.

The gas fraction contains high concentrations of methane, ethane, butadiene, hydrogen and other hydrocarbon gases [17,19]. With a GCV of approximately $37-42 \mathrm{MJ} / \mathrm{kg}$, it could provide all the energy required to run a pyrolytic process. However, the simple fact that the energy requirements of a process can be covered is insufficient to justify its use.

Recently, a team from the Centro Nacional de Investigaciones Metalúrgicas (CENIMCSIC) and the Instituto Nacional del Carbón (INCAR-CSIC), developed the GRAUTHERMIC-Tyres ${ }^{\circledR}$ process alongside ENRECO 2000 Ltd. [29-30]. This process, which operates at low temperature and atmospheric pressure, was designed for revalorising GSTs. Thermolysis proceeds in vertical, parallel, tubular reactors with no internal moving parts. During the thermolysis stage, there is very little oxygen present $(<3$ vol.\%); this prevents combustion reactions taking place. The gases that leave the reactor during this phase circulate through cooling and condensation systems. Those that do not condense are passed to a gas turbine for the production of electricity.

The present work examines the influence of thermolysis temperature (range $500-700^{\circ} \mathrm{C}$ ) on the products produced from GSTs by the GRAUTHERMIC-Tyres ${ }^{\circledR}$ process. Experiments were performed at batch scale in a pilot unit with a system for energetically revalorising the gases produced. The results obtained were compared to those reported in the literature for other pyrolytic processes.

\section{Experimental}

\subsection{Origin of the granulated material to be distilled and its chemical composition}

The GST used in this work came from the NEGRELL RESIDUES granulating plant (Banyoles, Gerona, Spain), and consisted of small particles (2-6 mm Ø) made of natural and synthetic rubber compounds (styrene butadiene rubber and butadiene rubber), elastomers, carbon black, hydrocarbon oils, zinc oxide, sulphur, sulphur compounds, stabilizers, antioxidants and anti-ozonants, and very small amount of fluff $(<2.0 \mathrm{wt} . \%)$ and steel $(<0.1 \mathrm{wt} . \%)$.

Proximate analyses were performed following standards ISO562 and ISO1171 to determine the volatile and ash contents respectively. Elemental analysis for $\mathrm{C}, \mathrm{H}, \mathrm{N}$ and $\mathrm{S}$ was carried out using a LECO CHNS 923 apparatus, following the method in standard ASTMA D5773. The GCV of the GST was estimated using an IKAWEEME C4000 automatic bomb 
calorimeter; for this, representative samples frozen in liquid nitrogen were first milled to a smaller particle size. Table 1 shows the composition of the raw GST to be similar to that reported in the literature [31-36].

\subsection{Thermolysis experiments}

Figure 1a shows the thermolysis unit. This consists of six vertical, tubular, stainless steel reactors (length $1510 \mathrm{~mm}$, wall thickness $6 \mathrm{~mm}$, external diameter $154 \mathrm{~mm}$ ). Each reactor has a capacity of $12 \mathrm{~kg}$ GST and is fed through a PN-16 3-type valve. The thermolysis gas flows out by natural convection and is cooled in two successive condensers (water- and cryogenically-cooled respectively) to recover the TDO. The condensers are composed of a number of stainless steel tubes. The upper and lower part of each is equipped with a small chamber for the expansion of gases and TDO collection. The gas temperature at the entrance of the first condenser is near $250^{\circ} \mathrm{C}$, and about $100^{\circ} \mathrm{C}$ at the exit. The gas reaches the second condenser at $45^{\circ} \mathrm{C}$. Gas condensation is enhanced by a cryogenic cooling system to guarantee a gas temperature below $5^{\circ} \mathrm{C}$ in the second condenser (Fig. 1b). The condensed oils are collected in a deposit equipped with a level-maintaining valve and a pump.

At the bottom of the reactor there is an external heating system that runs on propane gas. Each tube has three thermocouples, one at the bottom, one in the middle, and one at the top. These, like the rest of the monitoring systems, are connected to a central control unit. When the temperature of the reactor reaches $500,525,550,650$ or $700^{\circ} \mathrm{C}$ as desired, the burners switch off. Whenever the temperature falls, they automatically switch on again. The installation has an automated control system that records the temperature measured by the thermocouples.

The cold gas procedure is cleaned by a three filter system: water, a $1 \mathrm{M} \mathrm{Pb}\left(\mathrm{CO}_{3}\right)_{2}$ solution, and activated carbon. The clean gas passes through a flow meter to measure the volume and is conducted to a TOTEM ${ }^{\circledR}$ electric co-generation turbine (Total Energy Module) consisting of a thermolysis gas-fed $903 \mathrm{~cm}^{3}$ engine coupled to an engine/alternator (Fig. 1c). Both are asynchronous. The module has an electronic coupling system that diverts the electricity produced into the Spanish electricity grid, and has a system that measures the number of $\mathrm{kWh}$ produced.

Batches of GST (12 kg per tube) were heated for $4 \mathrm{~h}$ (treatment capacity $18 \mathrm{~kg} / \mathrm{h}$ ) at 500 , 525, 550, 650 and $700^{\circ} \mathrm{C}$. After completing the thermolysis process (the endpoint being deemed reached when the rotameter inside the tubing detected a total absence of thermolysis gas), the reactors were cooled for $4 \mathrm{~h}$, opened, and the thermolysis solids removed by aspiration. The TDO was taken from the deposit using a pump and filtered under pressure. The composition and yield (by weight) of the TDO and char fractions were then determined; the 
difference between the sum of these weights and the weight of the GST equals the weight of the gas. Each result presented in this paper is the mean value of the data obtained in at least two experiments.

\subsection{Characterisation of the tyre-derived oils}

Proximate analyses were performed following the ISO562 and ISO1171 procedures for volatile and ash content respectively. Elemental analyses $(\mathrm{C}, \mathrm{H}, \mathrm{N}$ and $\mathrm{S})$ of the TDOs produced at each thermolysis temperature were performed using a LECO CHNS 923 apparatus, following standard ASTMA D-5773. The amount of oxygen was calculated by difference. Their GCVs were determined using an IKAWEEME C4000 automatic bomb calorimeter.

The TDOs were dissolved in dichloromethane (DCM) and analysed by gas chromatography/mass spectrometry (GC/MS) using a GCMS-QP2010-Plus chromatograph (SHIMADZU, SCIENTIFIC INSTRUMENTS) equipped with a mass spectrometry detector (GC/MS) plus a TEKNOKROMA (TEKNOKROMA S. Coop. Ltda) TRB-5MS (95\% dimethyl-5\% diphenyl polysiloxane) capillary column (20 $\mathrm{m}$ in length, $0.1 \mathrm{~mm}$ diameter and $0.1 \mu \mathrm{m}$ film thickness). The carrier gas was helium. The GC/MS oven temperature programme used for the separation of the oil components was a follows: the oven was held at $40^{\circ} \mathrm{C}$ for 1 min, then ramped at $4^{\circ} \mathrm{C} / \mathrm{min}$ to $280^{\circ} \mathrm{C}$ where it was held for a further $25 \mathrm{~min}$. The MS detector performed scans across the 45 to 350 amu range. The ion-masses recorded were automatically compared to those in the NIST 08 spectra library; a similarity of $>95 \%$ was used to identify compounds. Samples were injected using an AOC-20i autoinjector (SHIMADZU).

The flashpoint of the TDOs was determined using a STANHOPE-SETA Setaflash 3 flashpoint analyser, employing the method outlined in standard ASTM D1655. The density of the TDOs was determined using a METTLER TOLEDO Densito 30 PX densitometer calibrated with distilled, deionised water from a Milli-Q Plus system (MILLIPORE). The kinematic viscosity was determined at $20^{\circ} \mathrm{C}$ and $40^{\circ} \mathrm{C}$ using a THERMO FISHER SCIENTIFIC Haake 1 plus viscosimeter.

\subsection{Characterisation of the thermolysis gas}

Once thermal equilibrium was achieved at the desired thermolysis temperatures, gas samples were taken from the non-condensed gas exit tube after having passed through the water, activated carbon and lead carbonate solution filters. All samples were captured in $1 \mathrm{~L}$ TEDLAR $^{\circledR}$ bags. They were then analysed using an HP 5890 gas chromatograph equipped with a thermal conductivity detector (TCD) and a flame ionisation detector (FID). Two packed 
columns were used in this analysis: (i) a Porapak N (3 $\mathrm{m} \times 1 / 8$ in. $)$ to separate $\mathrm{C} 1, \mathrm{C} 2, \mathrm{C} 3, \mathrm{C} 4$, $\mathrm{H}_{2} \mathrm{~S}$ and $\mathrm{CO}_{2}$, and (ii) a molecular sieve TM13x $\left(0.9 \mathrm{~m} \times 1 / 8\right.$ in.) to separate the $\mathrm{O}_{2}, \mathrm{~N}_{2}$, and CO. The Porapak column was heated from $50^{\circ} \mathrm{C}$ (maintained for $5 \mathrm{~min}$ ) to $185^{\circ} \mathrm{C}$ at a rate of $10^{\circ} \mathrm{C} / \mathrm{min}$. The $\mathrm{TM}$ column was held at $50^{\circ} \mathrm{C}$ throughout the experiment. Helium was used as the carrier gas. The temperature of the detectors was maintained at $300^{\circ} \mathrm{C}$. Quantification was performed by comparison against a blend of gases of known composition, the amount of hydrogen being calculated by difference. The electrical yield of the gases in the turbine was obtained as the ratio between the electricity produced and theoretical value output based on the composition of the gas, using equation (1):

$$
\mathrm{R}_{\mathrm{e}}(\%)=\left[\xi\left(\mathrm{kWh} / \mathrm{kg}_{\mathrm{GST}}\right) / \eta\left(\mathrm{kWh} / \mathrm{kg}_{\mathrm{GST}}\right)\right] * 100
$$

where $\xi$ represents the electricity produced $(\mathrm{kWh})$, expressed as a function of the quantity of GST treated (kilograms) and $\eta\left(\mathrm{kWh} / \mathrm{kg}_{\mathrm{GST}}\right)$, i.e., the theoretical $\mathrm{kWh}$ suggested by the composition of the gas.

\subsection{Characterisation of the thermolysis char}

The proximate, elemental compositions and the GCVs of the thermolysis chars obtained at each temperature were determined as for the TDOs. The oxygen content was determined directly using a LECO VTF-900 analyser.

The porous characteristics of the chars were analyzed by $\mathrm{N}_{2}$ adsorption at $77 \mathrm{~K}$ using a BECKMAN COULTER SA1100 automatic adsorption analyser. Samples $(0.30 \mathrm{~g}$ approximately) were degassed under vacuum at $200^{\circ} \mathrm{C}$ for $24 \mathrm{~h}$ prior to adsorption. The specific surface areas were estimated by the BET equation in the $p / p_{0}$ range $0.015-0.15,\left(r^{2}>0.9999\right)$. Dubinin's theory was used to provide information on the microporous structure of the solid residues. Complementary information was achieved by immersion calorimetry at 293K (TianCalvet type calorimeter) [37].

The crystalline phases in the char were characterized by X-ray diffraction (XRD) using a BRUKER XRD Mod. D8 Discover diffractometer $\left(\mathrm{Cu}_{\mathrm{k} \alpha}\right.$ radiation, $0.032 \theta^{\circ}$ step-widths, $5 \mathrm{~s}$ per step).

The chars were morphologically characterized by scanning electron microscopy (SEM) using a field emission JEOL JSM $6500 \mathrm{~F}$ microscope.

Chemical analysis of the ash was performed by combusting the char samples at $800^{\circ} \mathrm{C}$. The residue produced was disaggregated by alkaline fusion and dissolved using inorganic acids in a platinum crucible. $\mathrm{Zn}, \mathrm{Cu}, \mathrm{Fe}, \mathrm{Ti}, \mathrm{Al}, \mathrm{Ca}, \mathrm{Mg}$ and $\mathrm{Si}$ were measured by atomic absorption 
spectroscopy, and $\mathrm{K}$ and $\mathrm{Na}$ by atomic emission spectroscopy, using a SHIMADZU AA-6300 apparatus, employing a deuterium lamp for background correction (BGC-D2).

\section{Results and Discussion}

\subsection{Thermolysis}

\subsubsection{Thermolysis yields}

Figure 2 shows the influence of the thermolysis temperature on the gas and TDO yields. The reduction in TDO yield with increasing temperature and the corresponding increase in gas production has been reported by other authors [26]. These phenomena are attributed to the increased cracking of $\mathrm{C}-\mathrm{C}$ bonds at higher temperature, giving rise to shorter chain hydrocarbons. The effect on the char yield was moderate (39 to $44 \mathrm{wt} . \%$ from $500^{\circ} \mathrm{C}$ to $700^{\circ} \mathrm{C}$ ). This small increase is believed to be due to carbonaceous deposits generated during aromatisation secondary reactions.

\subsubsection{Tyre-derived oils}

\section{Chemical and physical properties}

Table 2 summarizes the main characteristics of the TDOs. Their chemical composition was notably influenced by the thermolysis temperature. The carbon and hydrogen contents decreased with increasing temperature and the $\mathrm{H} / \mathrm{C}$ ratio became smaller due to the marked aromatisation produced at $650^{\circ} \mathrm{C}$ and above. The TDOs showed densities of between 0.91 and $0.94 \mathrm{~kg} / \mathrm{m}^{3}$ at $20^{\circ} \mathrm{C}$, increasing slightly with the thermolysis temperature. Their kinematic viscosity ranged from $3.2-5.6 \mathrm{cSt}$ at $20^{\circ} \mathrm{C}$ to $2-3.3 \mathrm{cSt}$ at $40^{\circ} \mathrm{C}$, in each case falling with increasing thermolysis temperature. These densities and kinematic viscosities are similar to those of diesel oil. The flash point for all the TDOs was low $\left(<20^{\circ} \mathrm{C}\right)$ compared to refined petroleum fuels. For example, kerosene has a required minimum flash point of $23^{\circ} \mathrm{C}$, that of diesel fuel is $75^{\circ} \mathrm{C}$, and that of light oil $79^{\circ} \mathrm{C}$. The low flash points of the TDOs are not surprising since these oils are un-refined and contain a mixture of components with a wide range of boiling points. Almost identical physical properties, chemical composition and GCVs have been reported by other authors for other tyre pyrolysis liquids [38-39].

The GCVs (41-43 MJ/kg) of the present TDOs surpass those of conventional liquid fuels, indicative of their potential as alternatives to fossil fuels [31]. However, they require treatments such as decanting, centrifugation, filtration, desulphurisation and hydrotreatment before being used as such. 
Figure 3 shows the data obtained by distilling the TDOs using the ASTM D86 method. The TDOs covered a wide boiling point range, in agreement with that reported elsewhere [20]. The initial boiling point (IBP) of the TDOs varied from $77-107^{\circ} \mathrm{C}$, the final boiling point (FBP) being between $371^{\circ} \mathrm{C}$ and $348^{\circ} \mathrm{C}$. A drop in IBP was observed with increasing temperature.

Around 16-35 vol.\% (depending on the thermolysis temperature) corresponded to a fraction with a boiling point of $170^{\circ} \mathrm{C}, \approx 15$ vol. $\%$ fell into the range $160-200^{\circ} \mathrm{C}$, and $36-46$ vol. $\%$ had a boiling point between 200 and $350^{\circ} \mathrm{C}$. These values correspond to the limit boiling points of light naphtha, heavy naphtha and middle distillate respectively. Laresgoiti et al. [20] reported contributions of $20 \%, 10 \%$ and $35 \%$ respectively for car tyre-derived pyrolytic oils; for truck tyre-derived pyrolytic oils [38] the corresponding fractions were $40 \%, \approx 15 \%$ and $\approx 45 \%$. Islam et al. [39] indicated contributions of $35 \%, 15 \%$ and $45 \%$ for bicycle/rickshaw tyre pyrolysis oils.

To characterise the TDOs produced at the different thermolysis temperatures, they were boiled (i.e., distilled) and the fractions produced recorded (Fig. 4). These fractions fell into the following categories: gasoline $\left(<149^{\circ} \mathrm{C}\right)$, kerosene $\left(149-232^{\circ} \mathrm{C}\right)$, diesel $\left(232-343^{\circ} \mathrm{C}\right)$, fuel oil $\left(343-371^{\circ} \mathrm{C}\right)$, and heavy vacuum gas oil $\left(>371^{\circ} \mathrm{C}\right)$. The quantity of fuel oil remained rather constant in the TDOs produced at the different thermolysis temperatures. However, the amount of gasoline notably increased with the thermolysis temperature whereas that of diesel oil decreased. At temperatures between $500^{\circ} \mathrm{C}$ and $550^{\circ} \mathrm{C}$, the major fraction corresponded to kerosene and diesel. As the thermolysis temperature increased further $\left(650-700^{\circ} \mathrm{C}\right)$, the TDOs became enriched in molecules with lower boiling points.

\section{$G C-M S$}

The chemical composition of the TDOs was complex, including compounds with structures of $\mathrm{C}_{5}-\mathrm{C}_{34}$. The products identified at $500^{\circ} \mathrm{C}$ and $525^{\circ} \mathrm{C}$ were mainly composed of aromatic compounds $(80.1 \%$ area) and unsaturated hydrocarbons (7.6 and $7.8 \%$ area respectively). The oils derived at $650^{\circ} \mathrm{C}$ and $700^{\circ} \mathrm{C}$ were essentially made of aromatic compounds (93 and 94\% area respectively). Their precursors were unsaturated species since their proportion decreased from $8 \%$ area to $2.6 \%$ area as the temperature increased from $500^{\circ} \mathrm{C}$ to $700^{\circ} \mathrm{C}$. As reported elsewhere, the aromatic compounds derive from the pyrolysis of pure 
styrene-butadiene rubber [40]. The mono-aromatic compounds (benzene and their derivatives) contents were similar at all temperatures (average area 53.0\% $\pm 1.4 \%$ ).

Fractionation of the TDOs into chemical classes by GC/MS revealed a reduction in the percentage yield of aliphatic compounds with increasing temperature, accompanied by an increase in the generation of aromatic compounds. Higher thermolysis temperatures favour the production of polycyclic aromatic hydrocarbon (PAHs) (naphthalene, 1-methyl and 2-methyl naphthalene, dimethyl and trimethylnaphthalene, methyl, phenanthrene, anthracene and dimethyl indene, indane, $1 \mathrm{H}$-indane and methyl-biphenyl).

Sulphur PAHs (benzothiazol) and nitrogen PAHs (alkylated quinolines) were detected in the all TDOs. Benzothiazol was formed as a consequence of the decomposition of benzothiayldisulphide (used as an accelerator in tyre manufacture).

Table 3 summarizes the main components of the present TDOs. For the sake of simplicity, only those compounds with a percentage quantified area greater than $1 \%$ are included. In all cases, benzene and its derivatives were the most abundant products, with percentage areas ranging from $23 \%$ to almost $27 \%$. Other compounds such as toluene and its derivates (13-18\% area), naphthalene (11-20\% area), indene (10-13\% area) and xylene (6-13\% area) were also detected.

Finally, the contribution of monoterpenes (limonene and cumene) produced from the depolymerisation of natural rubber by the $\beta$-scission of double bonds or by monomer recombination via a Diesel-Alder reaction [40], was greater at thermolysis temperatures of 500$550^{\circ} \mathrm{C}(3-4 \%$ area $)$.

\subsubsection{Tyre thermolysis gases}

\section{Chemical composition}

Table 4 shows the composition of the gases evolved during thermolysis at $500-700^{\circ} \mathrm{C}$. The amount of C1 (methane), C2 (ethane and ethene) and C3 (propane and propene) increased with increasing thermolysis temperature, while the amount of $\mathrm{C} 4$ components (n-butane, isobutane and 1-butene) decreased. The $\mathrm{C} 4$ components originate from the depolymerisation of styrene-butadiene rubber.

The $\mathrm{CO}_{\mathrm{x}}$ content fell with increasing thermolysis temperature $\left(8.7\right.$ vol.\% at $500^{\circ} \mathrm{C}$ and 2.9 vol. $\%$ at $\left.700^{\circ} \mathrm{C}\right) . \mathrm{CO}_{\mathrm{x}}$ compounds derive from oxygenated organic compounds, such as stearic acid and extender oils, and fluff fibres adhered to the rubber, and even from inorganic 
components, such as $\mathrm{CaCO}_{3}$. The GCVs of the gases produced at each temperature, calculated taking into account their composition, were very high (64-85 $\left.\mathrm{MJ} / \mathrm{Nm}^{3}\right)$. An increase in temperature involves a reduction in the calorific value of the gas produced since longer chain hydrocarbons decrease in favour of lighter hydrocarbons and hydrogen.

The literature contains references to tyre pyrolysis gases with GCVs in the range of $30-$ $40 \mathrm{MJ} \mathrm{N} / \mathrm{m}^{3}$ [41-42] - much lower than those obtained in the present study. The volume of gases produced per unit mass of GST ( $\mathrm{Y}_{\mathrm{g}}$ ) increased from $0.46 \mathrm{Nm}^{3} / \mathrm{kg}_{\mathrm{GST}}$ at $500^{\circ} \mathrm{C}$ to 0.67 $\mathrm{Nm}^{3} / \mathrm{kg}_{\mathrm{GST}}$ at $700^{\circ} \mathrm{C}$ (see Table 4 ).

Table 4 shows that the electricity produced from GST $(\xi)$ to be $4.1-6.6 \mathrm{kWh} / \mathrm{kg}$. The electrical yield $\left(\mathrm{R}_{\mathrm{e}}\right)$, increased with the thermolysis temperature from $39 \%$ at $500^{\circ} \mathrm{C}$ to $59 \%$ at $700^{\circ} \mathrm{C}$, in agreement with the variation in the volume of gas produced. The quantity of gases obtained at $500-525^{\circ} \mathrm{C}$ was insufficient to keep the turbine running, but this was not the case at the other temperatures. Turning the thermolytically-produced gases into electricity is an interesting way of making use of them. In other pyrolytic processes, the gases produced pass through a heat exchanger, and the energy captured is used to heat the pyrolysis reactor.

As shown in Table 5, 72-78.3\% of the sulphur contained in the tyre remained in the solid and liquid fractions, the rest appearing in the gaseous fraction (21.7-28\%). In fact, the sulphur was mostly retained in the char product, this retention increasing with temperature [43].

The decomposition of sulphur bonds generated sulphidric acid in the thermolysis gases. After filtering, the concentration of sulphidric acid in the thermolysis gases was rather low (0.80.9 vol.\%), despite the GSTs containing 1.8 wt.\% sulphur. No significant variation in $\mathrm{H}_{2} \mathrm{~S}$ production was observed at the different thermolysis temperatures.

\subsubsection{Thermolysis char}

The solid obtained was a granulated black product, made of the initial mineral matter, the carbon blacks used in the manufacture of the tyres, and the carbonaceous material derived by secondary repolymerisation reactions among the polymer-derived products.

As the thermolysis temperature increased from $500^{\circ} \mathrm{C}$ to $650^{\circ} \mathrm{C}$, the content in volatile material, ash, hydrogen and oxygen decreased, while the fixed carbon content (78.9-81.3 wt.\%) increased slightly (Table 6). The GCV of the chars was 27.6-28.6 MJ/kg, i.e., hardly changing with the thermolysis temperature. 
All the chars had relatively high ash (17-21 wt.\%) and S (2.4-3.1 wt.\%) contents. The ashes were made of $\mathrm{Si}$ and $\mathrm{Zn}$ and to a lesser extent of $\mathrm{Na}$ and $\mathrm{Ca}$. Si and $\mathrm{Zn}$ are mainly added as oxides in tyre manufacture, $\mathrm{SiO}_{2}$ as a filler and $\mathrm{ZnO}$ as a vulcanisation catalyst. Table 6 shows the chemical composition of the ashes (expressed as oxides) produced at different temperatures. No significant change was observed with thermolysis temperature: the contents in $\mathrm{ZnO}, \mathrm{SiO}_{2}$ and $\mathrm{CaO}$ was 27-28 wt.\%, 52-54 wt.\%, and 4.0-4.6 wt.\% respectively. The presence of $\mathrm{CaO}$ is a consequence of the use of $\mathrm{CaCO}_{3}$ in the tyre manufacturing process.

X-ray diffraction analysis of the crystalline phases of the char revealed their clear dependence on the thermolysis temperature. The diffractograms obtained at $500-550^{\circ} \mathrm{C}$ were similar, with the crystalline phases corresponding to $\alpha$ - and $\beta$-ZnS (wurtzite, sphalerite) and $\mathrm{PbS}$ (Fig. 5a). Scanning electron microscopy analysis revealed spherical $\mathrm{ZnS}$ particles on the char surface (inset in Fig. 5a). At $650^{\circ} \mathrm{C}$ and $700^{\circ} \mathrm{C}$, however, the crystalline phases in the char were mainly of zincite $(\mathrm{ZnO})$, willemite $\left(\alpha-\mathrm{Zn}_{2} \mathrm{SiO}_{4}\right)$, sodium zinc silicate $\left(\mathrm{Na}_{2} \mathrm{Zn}_{3}\left(\mathrm{SiO}_{4}\right)_{2}\right)$ and zinc silicate $\left(\beta-\mathrm{Zn}_{2} \mathrm{SiO}_{4}\right)$ (Fig. 5b). The inset SEM image in Figure 5b shows cubic and hexagonal zincite crystals on the char surface.

The chars produced have a largely macroporous (>50 nm, IUPAC classification) structure with cavities over $100 \mathrm{~nm}$ across (see Table 6). The volume of the micropores $(<2 \mathrm{~nm})$ and mesopores $(2-50 \mathrm{~nm})$ was very small in all the samples analysed. The total pore volume $\left(\mathrm{V}_{\mathrm{T}}\right)\left(p / p_{o}=0.98\right)$ varied between 0.4 and $0.5 \mathrm{~cm}^{3} / \mathrm{g}$. The specific BET surface area increased over the $500-550^{\circ} \mathrm{C}$ thermolysis temperature range, but became smaller above these temperatures. The shapes of the $\mathrm{N}_{2}$ isotherms (not shown) were characteristic of a macroporous solid, with very little $\mathrm{N}_{2}$ adsorption at low pressure but with a rapid increase in adsorption at relative pressures $\left(p / p_{0}\right)$ above 0.8 . Analysis of the $\mathrm{N}_{2}$ adsorption isotherms using the DubininRadushkevich equation returned $E_{o}$ energies of around $12-13 \mathrm{~kJ} / \mathrm{mol}$. These values, all under 16 $\mathrm{kJ} / \mathrm{mol}$ confirm a lack of significant microporosity. The enthalpy of immersion in benzene $\left(-\Delta_{\mathrm{i}} \mathrm{H}\right.$ $\left.\left(\mathrm{C}_{6} \mathrm{H}_{6}\right)\right)$ was $<9 \mathrm{~J} / \mathrm{g}$ for all the chars produced, falling with increasing thermolysis temperature. This confirms their little-developed micro- and mesoporous texture. The chars produced showed textural properties similar to N 550 (BET surface area $\left.43 \mathrm{~m}^{2} / \mathrm{g}\right), \mathrm{N} 660\left(36 \mathrm{~m}^{2} / \mathrm{g}\right)$ and N $774\left(28 \mathrm{~m}^{2} / \mathrm{g}\right)$ carbon blacks [44].

Table 7 shows simple mass and energy balances for the studied process. The mass balance refers to $1000 \mathrm{~kg}$ of GST. The values shown were obtained from the recovery masses for the TDO, char and gases (see Fig. 2). The values for the energy balance were obtained from the GCV of the GST, TDO, char, gases, and the propane used. The consumption of propane involved in heating the reactor varied between 150 and $154 \mathrm{~kg} / \mathrm{T}_{\mathrm{GST}}$, with consumption at its 
highest until a temperature of $450-500^{\circ} \mathrm{C}$ was reached - a consequence of the thermal inertia of the GST decomposition reactions. The energy contained within the thermolysis gases was similar to or higher than that provided by the propane. This indicates that, as well as using the gases for producing electricity, they could very well be used to heat the reactors. The final energy balance shows that some $77-82 \%$ of the energy input (i.e., that provided by the GST and the propane) can be recovered, with energy losses increasing with the thermolysis temperature.

\section{Conclusions}

The yields of gas, TDO and char (15-22 wt.\%, 34-46 wt.\% and 39-44 wt.\%, values that represent major recoveries from the GST feedstock) produced were similar to those obtained by pyrolysis in an oxygen-free environment.

The yields of TDO and gas were inversely related. An increase in the char yield was observed with increasing thermolysis temperature, probably due to the generation of carbonaceous deposits.

The TDO fraction was mainly a mixture of aliphatic and aromatic hydrocarbons. A large increase was seen in the $\mathrm{PAH}$ content at temperatures above $550^{\circ} \mathrm{C}$, while the monoaromatic compound content remained practically constant over the studied temperature range. The TDOs had very high GCVs (41-43 MJ/kg), higher than those of conventional liquid fuels. They might therefore be used as alternatives to the latter.

An increase in $\mathrm{C}_{1}-\mathrm{C}_{4}$ gases was seen as the thermolysis temperature rose. The noncondensable gas obtained had high GCVs $\left(64-83 \mathrm{MJ} / \mathrm{Nm}^{3}\right)$. Large amounts of electricity can be produced from the gases in gas turbines (4.1-6.5 $\mathrm{kWh} / \mathrm{kg}$ of GST).

The chars obtained had a moderate GCV (27-28 MJ/kg), high ash (17-21 wt.\%) and zinc contents, low BET surface areas $\left(46-78 \mathrm{~m}^{2} / \mathrm{g}\right)$, and a mainly macroporous texture. Their high ash content is clearly a drawback; a demineralisation process would be needed to recover them as carbon blacks. Sulphur was preferentially retained in the char, increasingly so with rising temperature.

The optimum temperature for the present process appears to be $550^{\circ} \mathrm{C}$. At this temperature some $80 \%$ of the energy contained within the GST is recovered.

The thermolysis of GSTs and co-generation of gases by the GRAUTHERMIC-Tyres ${ }^{\circledR}$ process would appear to be a viable means of valorising GST.

\section{Acknowledgements}

This work was performed with the financial support of ENRECO $2000 \mathrm{Ltd}$. 


\section{REFERENCES}

[1] Juniper Consultancy Services Ltd, Emerging solutions for managing scrap tyres. Technology solutions and market opportunities. Sheppards Mill (Ed.), Gloucestershire, England, 2004, pp. 22-23

[2]. G. Ramos, F. J. Alguacil and F. A. López, The recycling of end-of-life tyres. Technological review, Rev. Metal. 47 (2011) 273-284.

[3] J.A. Conesa, I. Martin-Gullón, R. Font and J. Jauhiainen, Complete study of the pyrolysis and gasification of scrap tires in a pilot plant reactor, Environ. Sci. Technol. 38 (2004) 3189 3194.

[4] M.R. Islam, H. Haniu and M.R.A. Beg, Liquid fuels and chemicals from pyrolysis of motorcycle tire waste: product yields, compositions and related properties, Fuel 87 (2008) $3112-3122$

[5] S.Q. Li, Q. Yao, Y. Chi, J.H. Yan and K.F. Cen, Pilot-scale pyrolysis of scrap tires in a continuous rotary kiln reactor, Ind. Eng. Chem. Res. 43 (2004) 5133-5145

[6] E. Aylon, A. Fernández-Colino, M.V. Navarro, R. Murillo, T. García and A.M. Mastral, Waste tire pyrolysis: comparison between fixed bed reactor and moving bed reactor, Ind. Eng. Chem. Res. 47 (2008) 4029-4033

[7] X. Dai, X. Yin, C. Wu, W. Zhang and Y. Chen, Pyrolysis of waste tires in a circulating fluidized-bed reactor, Energy 26 (2001) 385-399

[8] W. Kaminsky, C. Mennerich and Z. Zhang, Feedstock recycling of synthetic and natural rubber by pyrolysis in a fluidized bed, J. Anal. Appl. Pyrolysis 85 (2009) 334-337.

[9] C. Roy, A. Chaala and H. Darmstadt, The vacuum pyrolysis of used tires : end-uses for oil and carbon black products, J. Anal. Appl. Pyrolysis 51 (1999) 201-221

[10] J.R. Kim, J.S. Lee, S.D. Kim, Combustion characteristics of shredded waste tires in a fluidized-bed combustor, Energy 67 (1994) 845-854.

[11] A. Atal, Y.A. Levendis, Comparison of the combustion behavior of pulverized waste tires and coal, Fuel 74 (1995) 1570-1581.

[12] Y.A. Levendis, A. Atal, J. Carlson, Y. Dunayevskiy, P. Vouros, Comparative study on the combustion and emissions of waste tire crumb and pulverized coal, Environ. Sci. Technol. 30 (1996) 2742-2754.

[13] Y. Tang, C.W. Curtis, Thermal and catalytic coprocessing of waste tires with coal, Fuel Proc. Technol. 46 (1996) 195-215

[14] A.M. Cunliffe, P.T. Williams, Influence of process conditions on the rate of activation of chars derived from pyrolysis of used tires, Energy Fuels 13 (1999) 166-175 
[15] M. Olazar, M. Amutio, R. Aguado and J. Bilbao, Influence of tire formulation on the products of continuous pyrolysis in a conical spouted bed reactor, Energy Fuels 23 (2009) $5423-5431$

[16] B. Shen, C. Wu, R. Wang, B. Guo and C. Liang, Pyrolysis of scrap tyres with zeolite USY, J. Hazard. Mater. 137 (2006) 1065-1073

[17] F. Murena, E. Garufi, R.B. Smith and F. Gioia, Hydrogenative pyrolysis of waste tires, J. Hazard. Mater. 50 (1996) 79-98

[18] J. Piskorz, P. Majerski, D. Radlein, T. Wik, D.S. Scott, Recovery of carbon black from scrap rubber, Energy Fuels 13 (1999) 544-551.

[19] J.F. González, J.M. Encinar, J.L. Canito, J.J. Rodríguez, Pyrolysis of automobile tyre waste. Influence of operating variables and kinetics study, J. Anal.Appl. Pyrolysis 58-59 (2001) $667-683$.

[20] M.F. Laresgoiti, B.M. Caballero, I. de Marco, A. Torres, M.A. Cabrero, M.J. Chomón, Characterization of the liquid products obtained in tyre pyrolysis, J. Anal. Appl. Pyrolysis 71 (2004) 917-934

[21] Boletín Oficial del Estado. 215 (2010) 76442-445

[22] ISO 4259. Petroleum products- Determination and application of precision data in relation to methods test.

[23] Catalonian Autonomous. DOGC 2166/1996. Decreto 34/1996

[24] P.T. Williams, A.J. Brindle, Aromatic chemicals from the catalytic pyrolysis of scrap tyres, J. Anal. Appl. Pyrolysis 67 (2003) 143-164

[25] C. Roy, H. Darmstadt, Carbon blacks recovered from robber waste by vacuum pyrolysis comparison with commercial grades, Plast. Rub. Comp. Proc. Appl. 27 (1998) 341

[26] O.S. Chan, W.H. Cheung, G. McKay, Preparation and characterisation of demineralised tyre derived activated carbon, Carbon 49 (2011) 4674-4687

[27] J.Zhu, B.Shi, L.Chen, D.Liu , H.Liang, Production, characterization and properties of chloridized mesoporous activated carbon from waste tyres, Waste Manag.Res. 27 (2009) 553560 .

[28] G. López, M. Olazar, M. Artetxe, M. Amutio, G. Elordi, J. Bilbao, Steam activation of pyrolytic tyre char at different temperaturas, J. Anal. Appl. Pyrolysis 85 (2009) 539-543

[29] F. A. López, T.A. Centeno, F.J. Alguacil, B. Lobato, Distillation of granulated scrap tires in a pilot plant, J. Hazard. Mater. 190 (2011) 285-292.

[30] F.A.López, T.A. Centeno, F.J. Alguacil, B. Lobato, A. López-Delgado, J. Fermoso, Gasification of the char derived from distillation of granulated scrap tyres, Waste Manage. 32 (2012) 743-752. 
[31] S. Murugan, M.C. Ramaswamy and G. Nagarajan, Assessment of pyrolysis oil as an energy source for diesel engines, Fuel Process. Technol. 90 (2009) 67-74.

[32] S. Ucar, S. Karagoz, A.R. Ozkan and J. Yanik, Evaluation of two different scrap tires as hydrocarbon source by pyrolysis, Fuel 84 (2005) 1884-1892

[33] S. Galvagno, G. Casciaro, S. Casu, M. Martino, M. Mingazzini, C. Russo and S. Portofino, Steam gasification of tyre waste, poplar, and refuse-derived fuel: a comparative analysis, Waste Manage. 29 (2009) 678-689

[34] A.M.Fernández, C.Barriocanal, R. Alvarez, Pyrolysis of a waste from the grinding of scrap tyres, J.Hazard.Mater. 203-204 (2012) 236-243.

[35] M.A. Karel and M.H. Blumenthal, Air regulatory impacts of the use of tire -derived fuel, Environ. Prog. 20 (2001) 80-86.

[36] A. Donatelli, P. Iovane and A. Molino, High energy syngas production by waste tyres steam gasification in a rotary kiln pilot plant, Experimental and numerical investigations, Fuel 89 (2010) 2721-2728.

[37] T.A. Centeno and F. Stoeckli, The assessment of surface areas in porous carbons by two model-independent techniques, the DR equation and DFT, Carbon 48 (2010) 2478-2486.

[38] M. R. Islam, H. Haniu, M. R.A. Beg, Liquid fuels and chemicals from pyrolysis of motorcycle tire waste: Product yields, compositions and related properties, Fuel 87 (2008) 3112-3122.

[39] M.R.Islam, M.S.H.K. Tushar and H. Haniu, Production of liquid fuels and chemicals from pyrolysis of Bangladeshi bicycle/rickshaw tires wastes, J.Anal.Appl.Pyrolysis 82 (2006) 96109.

[40] E.Kwon, M.J. Castaldi, Investigation of Mechanisms of Polycyclic Aromatic Hydrocarbons (PAHs) Initiated from Thermal Degradation of Styrene Butadiene Rubber (SBR) in $\mathrm{N}_{2}$ Atmosphere, Environ. Sci. Technol. 42 (2008) 2175-2180

[41] M.F. Laresgoiti, I. De Marco, A. Torres, B. Caballero, M.A. Cabrero, M.J. Chomón, Chromatographic analysis of the gases obtained in tyre pyrolysis, J.Anal. Appl. Pyrol. 55 (2000) 43-54

[42] D.Y.C. Leung, X.L. Yin, Z.L. Zhao, B.Y. Xu, Y. Chen. Pyrolysis of tire powder: influence of operation variables on the composition and yields of gaseous product, Fuel Process. Technol. 79 (2002) 141-155 153

[43] L. Tang, H. Huang. An investigation of sulphur distribution during thermal plasma pyrolysis, J.Anal.Appl.Pyrolysis 72 (2004) 35-40

[44] M.Olazar, R.Aguado, M. Arabiourrutia, G.Lopez, A.Barona, J.Bilbao, Catalyst effect on the composition of tire pyrolysis products, Energ.Fuel.22 (2008) 2909-2916. 
Table Legends

Table 1 Proximate and elemental analyses of the scrap tyres used in this work, and comparison with other values quoted in the literature.

Table 2 Main characteristics of the tyre-derived oils.

Table 3 Main components of the tyre-derived oils determined by CG-MS (\%area).

Table 4 Composition (vol.\%) and main characteristics of the thermolysis gases and production of electricity at different thermolysis temperatures.

Table 5 Sulphur in the solid and tyre-derived oil fractions.

Table 6 Main characteristics of the chars.

Table 7 Mass and energy balance. 


\section{Figure Captions}

\section{Figure 1}

a) Semi-batch pilot plant.

(1): Reactor positions; (2) Condensers; (3) TDO collection tank.

b) TOTEM $^{\circledR}$ electric co-generation turbine.

Figure 2 Effect of temperature on the products yield.

Figure 3 Boiling point distribution of the tyre-derived oils compared to petroleum products.

Figure 4 Variation in the fraction categories obtained after boiling the tyre-derived oils produced at the different thermolysis temperatures.

Figure $5 \mathrm{X}$-ray diffraction patterns for the chars obtained at:

a) $550^{\circ} \mathrm{C}$. $(\mathrm{W}=$ wurtzite $(\alpha-\mathrm{ZnS}), \mathrm{S}=$ sphalerite $(\beta-\mathrm{ZnS})$ and $\mathrm{L}=$ lead sulphide $(\mathrm{PbS})$. Inset: SEM image showing a spheroidal particle of $\mathrm{ZnS}$ in the thermolysis char.

b) $650^{\circ} \mathrm{C} .\left(\mathrm{Z}=\right.$ zincite $(\mathrm{ZnO}), \mathrm{W}_{\mathrm{i}}=$ willemite $\left(\alpha-\mathrm{Zn}_{2} \mathrm{SiO}_{4}\right), \mathrm{SZS}=$ sodium zinc silicate $\left(\mathrm{Na}_{2} \mathrm{Zn}_{3}\left(\mathrm{SiO}_{4}\right)_{2}\right.$ and $\mathrm{ZS}=$ zinc silicate $\left(\beta-\mathrm{Zn}_{2} \mathrm{SiO}_{4}\right)$. Inset: SEM image showing hexagonal crystalline zincite in the thermolysis char. 
Fig 1a

Fig 1b
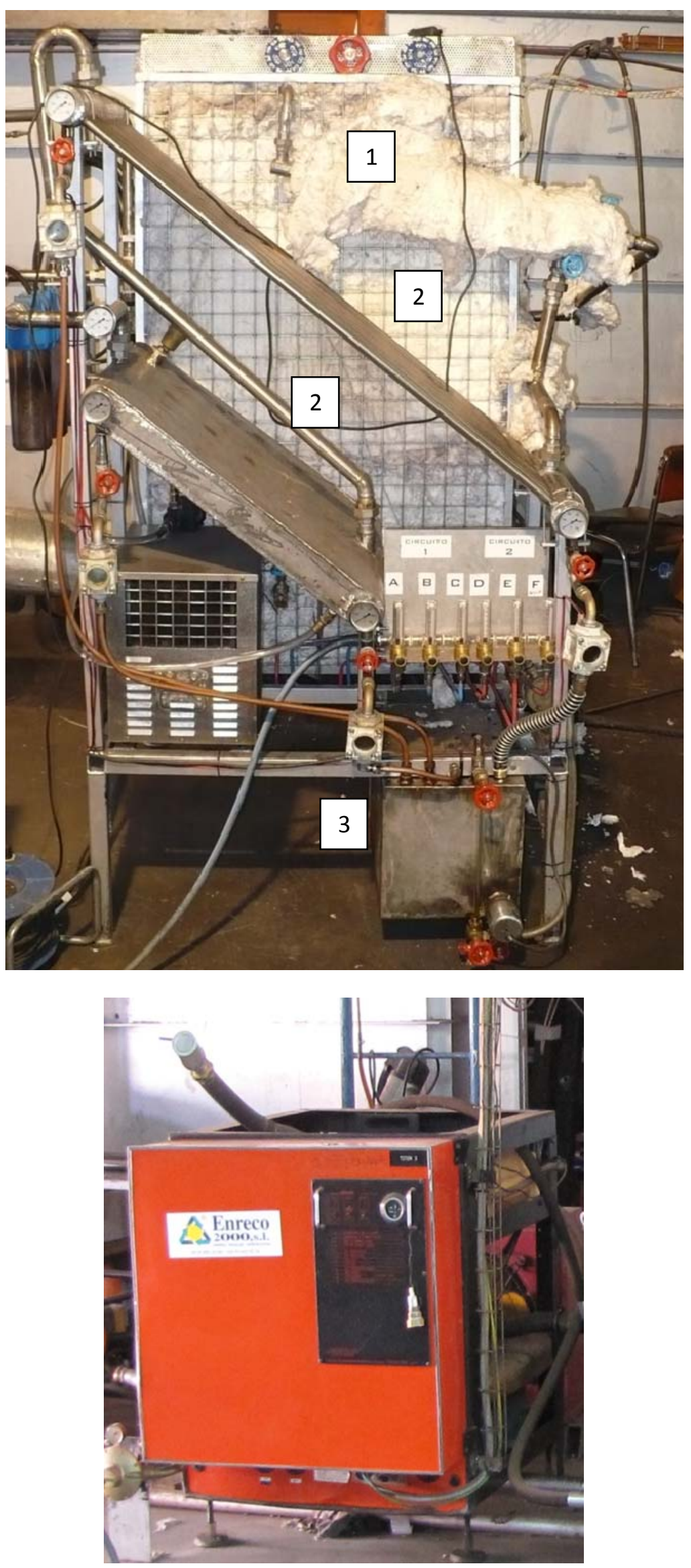


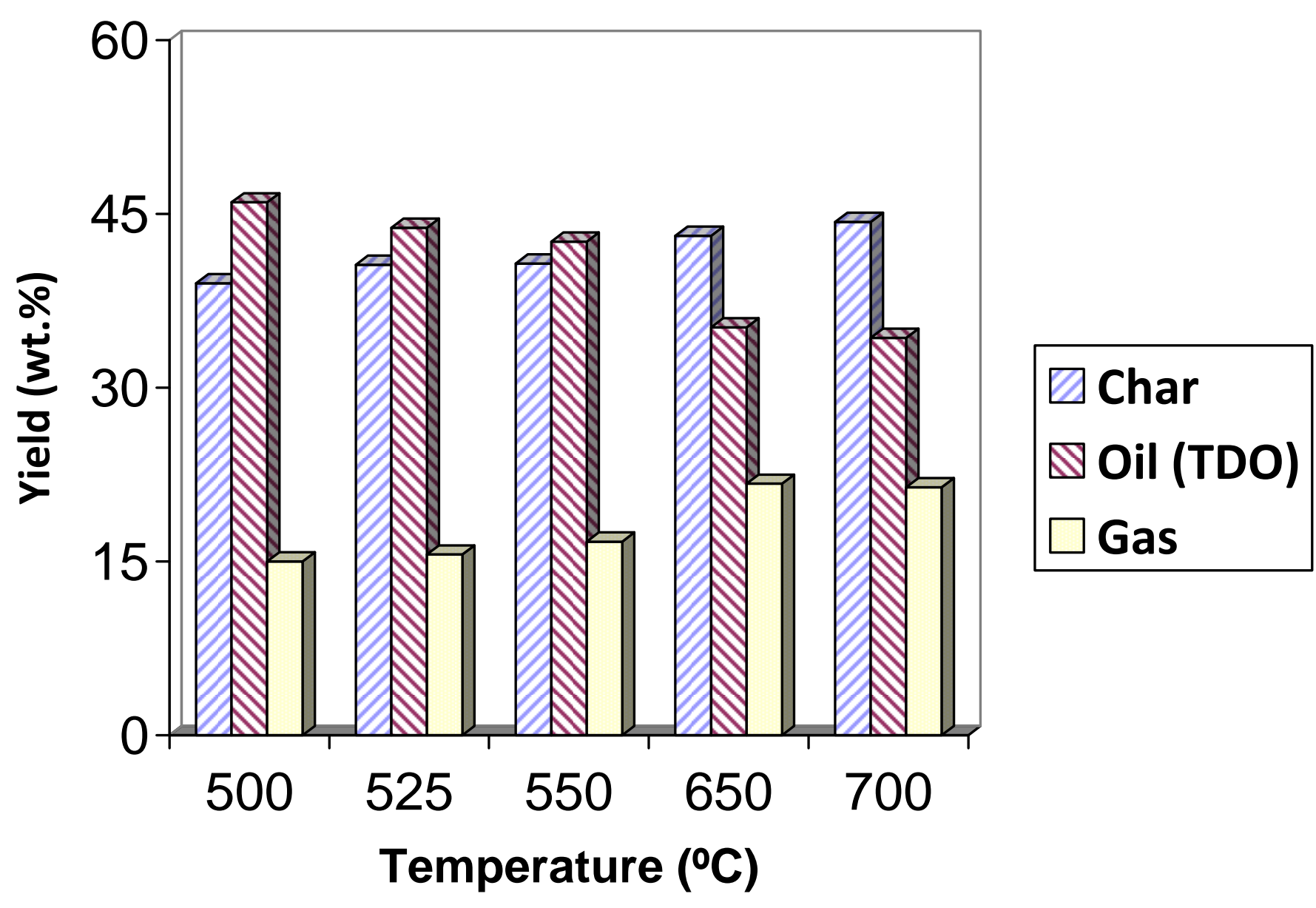




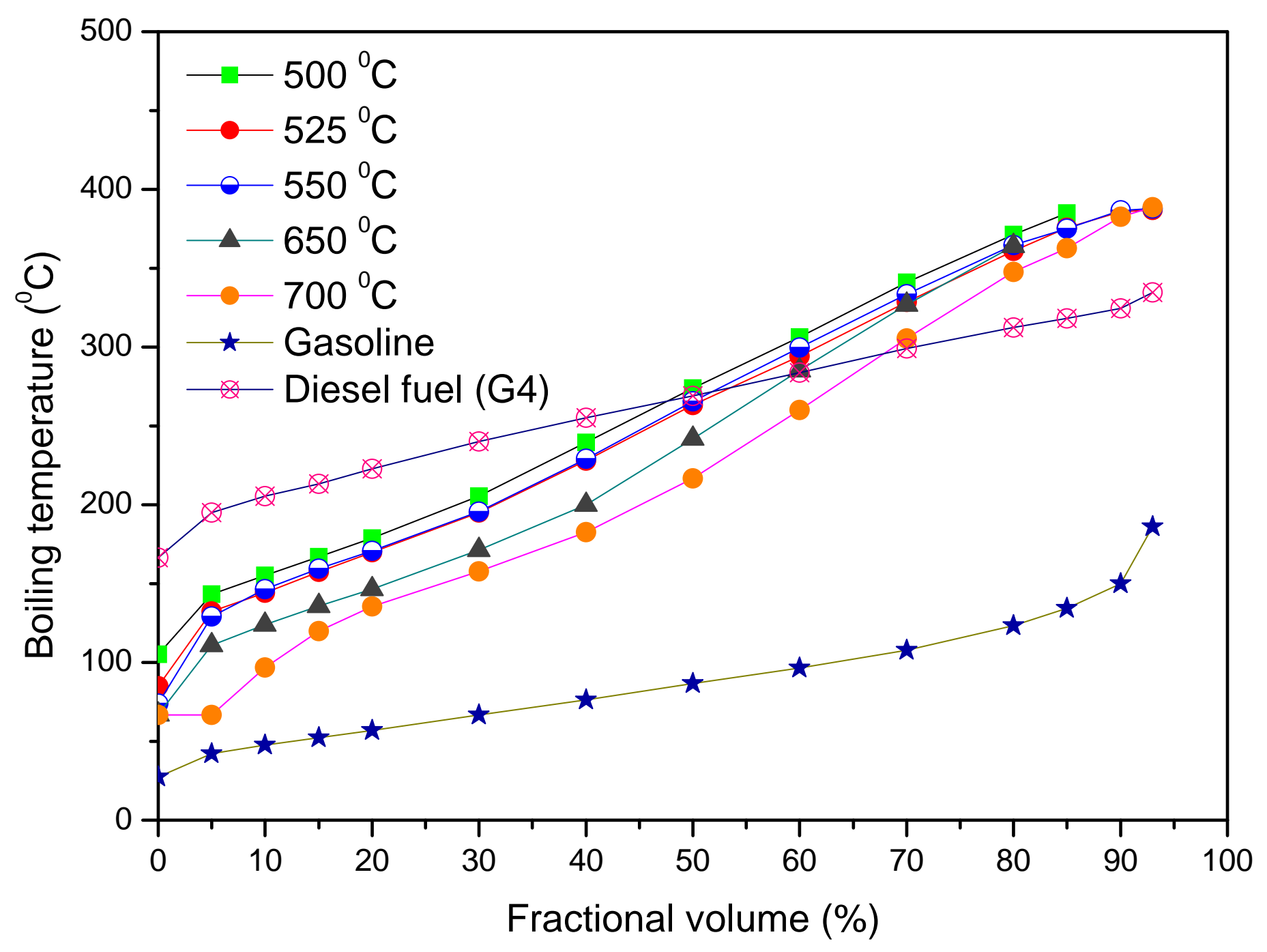


Figure 4

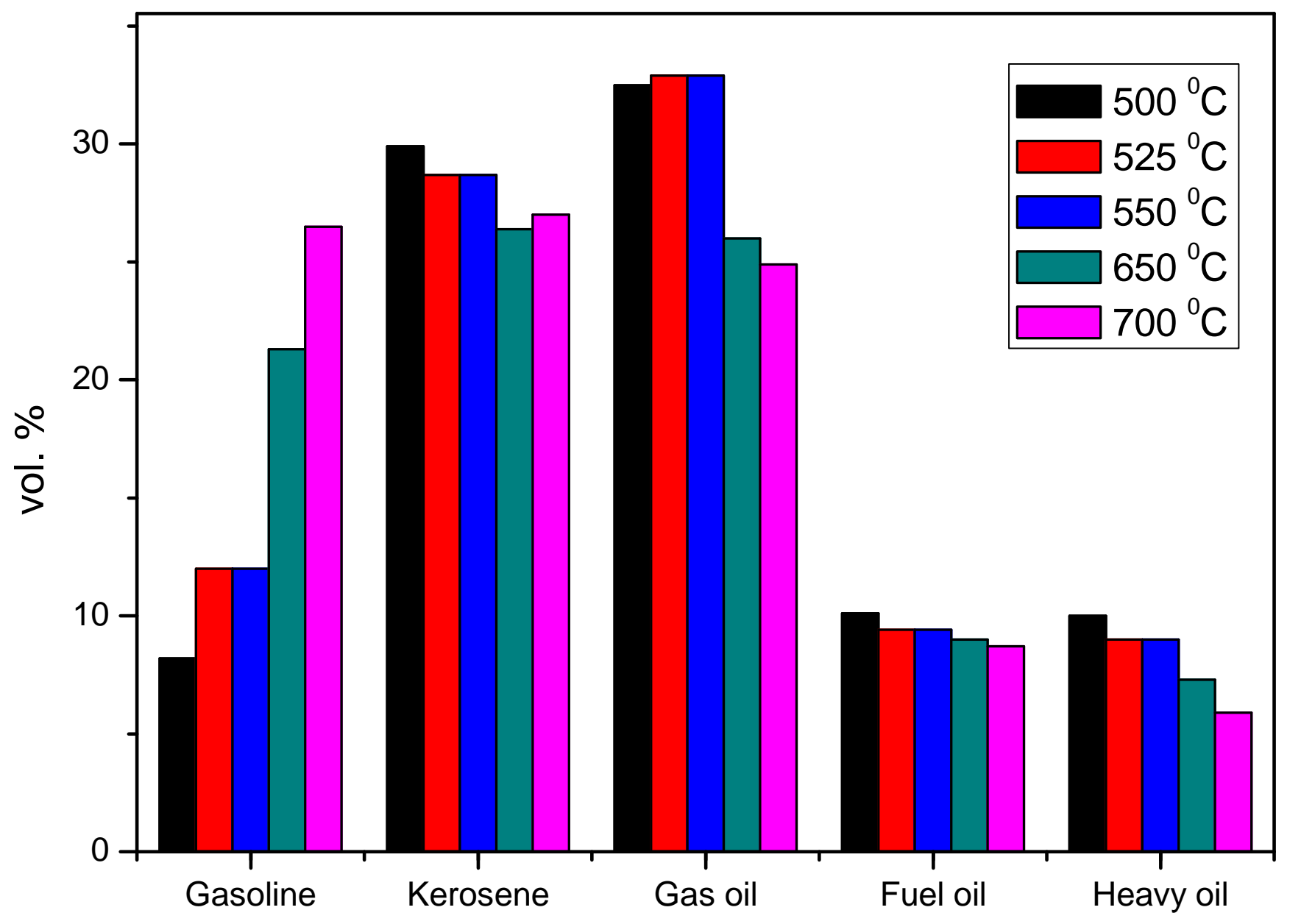




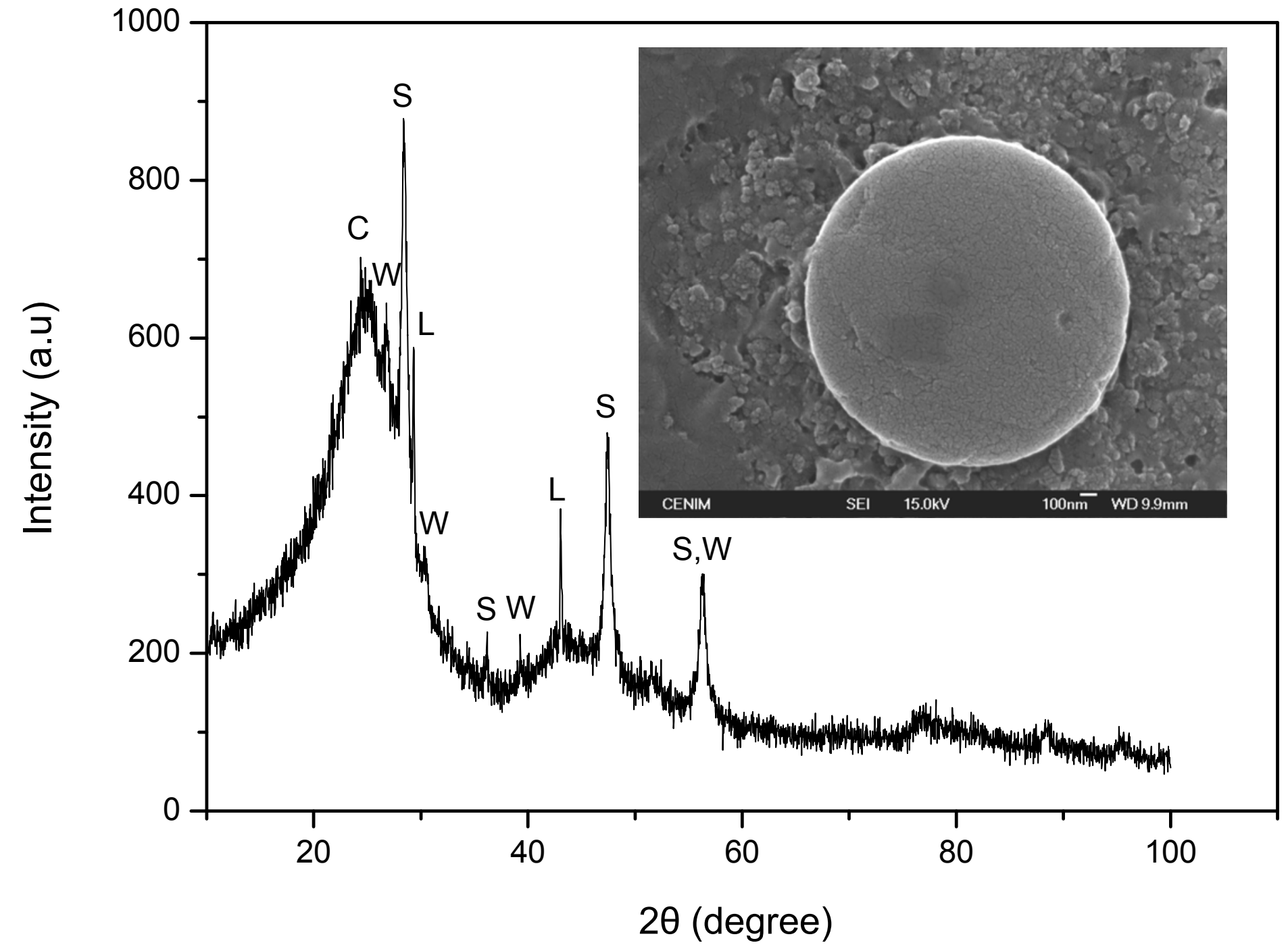


Figure 5b

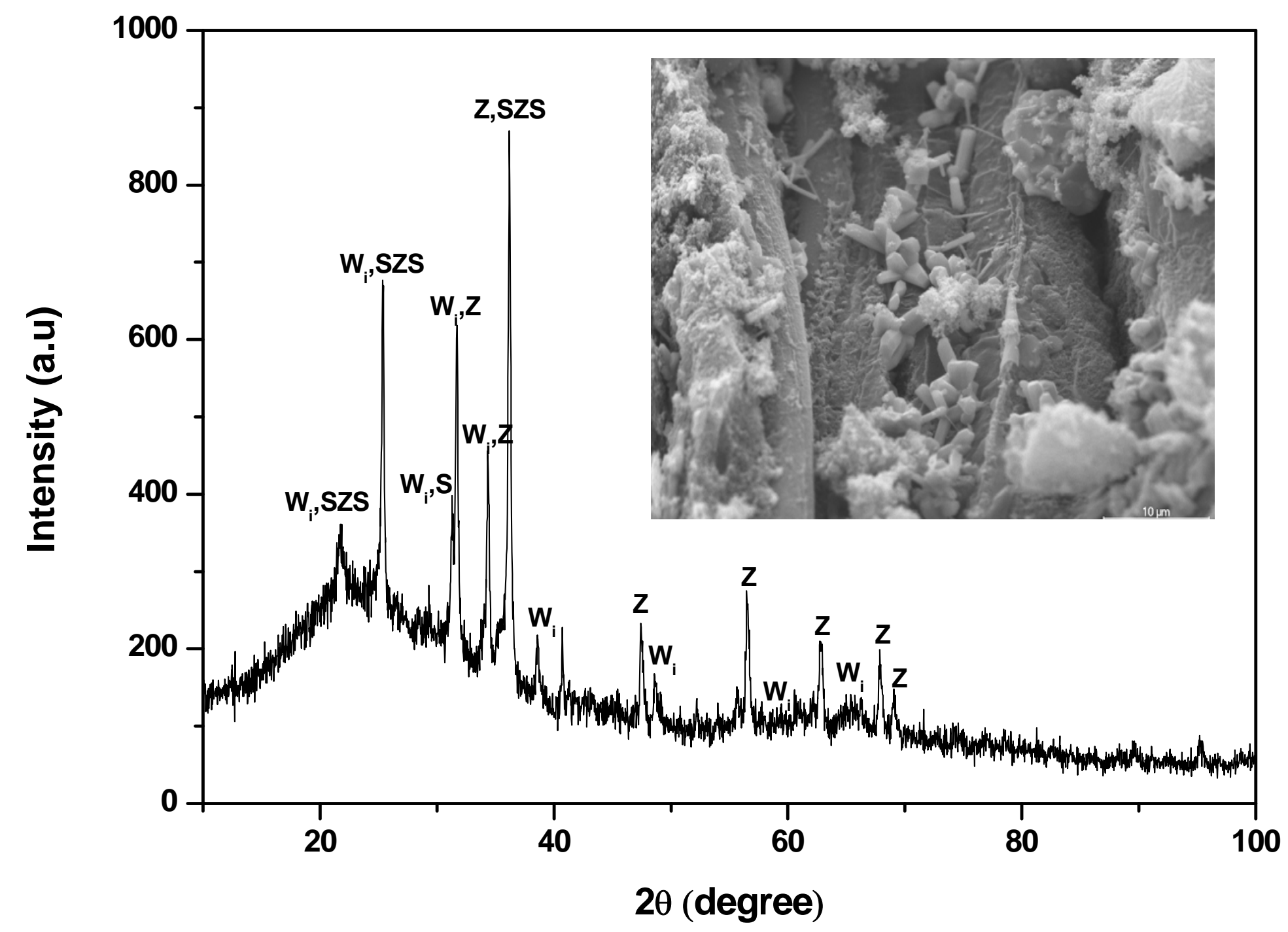


Table 1. Proximate and elemental analysis of scrap tyres used in this work and comparison with other values quoted in the literature.

\begin{tabular}{|c|c|c|c|c|c|c|c|}
\hline & $\begin{array}{c}\text { Present } \\
\text { paper }^{\dagger}\end{array}$ & $\begin{array}{c}\text { Murugan } \\
\text { et al. } \\
\text { [31] }\end{array}$ & $\begin{array}{l}\text { Ucar } \\
\text { et al. } \\
{[32]}\end{array}$ & $\begin{array}{c}\text { Galvagno } \\
\text { et al. } \\
\text { [33] }\end{array}$ & $\begin{array}{c}\text { Fernández } \\
\text { et } a l^{\dagger} \text {. } \\
\text { [34] }\end{array}$ & $\begin{array}{l}\text { Karell } \\
\text { et al. } \\
\text { [35] }\end{array}$ & $\begin{array}{c}\text { Donatelli } \\
\text { et } a l^{\dagger} \text {. } \\
\text { [36] }\end{array}$ \\
\hline Moisture $(w t \% d b)^{a}$ & 0.8 & 0 & 1.4 & 1.2 & - & 0.6 & 0.8 \\
\hline Volatile matter $(\mathrm{wt} \% \mathrm{db})^{\mathrm{a}}$ & 66.0 & 67.1 & 67.0 & 61.3 & 63.0 & 66.6 & 61.8 \\
\hline Ash $(w t \% d b)^{a}$ & 8.2 & 4.8 & 5.1 & 5.2 & 9.3 & 4.8 & 4.4 \\
\hline Fixed carbon (wt $\% \mathrm{db})^{\mathrm{b}}$ & 25.0 & 28.1 & 27.9 & 33.5 & 27.7 & 28.6 & 33.8 \\
\hline $\mathrm{C}(\mathrm{wt} \% \mathrm{daf})^{\mathrm{c}}$ & 88.4 & 83.5 & 83.2 & 85.2 & 87.6 & 88.1 & 89.1 \\
\hline $\mathrm{H}(\mathrm{wt} \% \mathrm{daf})^{\mathrm{c}}$ & 7.2 & 13.1 & 7.7 & 7.3 & 7.6 & 7.4 & 7.6 \\
\hline $\mathrm{N}(\mathrm{wt} \% \mathrm{daf})^{\mathrm{c}}$ & 0.3 & 0.2 & 1.5 & 0.4 & 0.3 & 0.2 & 0.4 \\
\hline $\mathrm{S}(\mathrm{wt} \% \mathrm{daf})^{\mathrm{c}}$ & 1.8 & 0.7 & 1.4 & 2.3 & 2.0 & 1.3 & 2.4 \\
\hline $\mathrm{O}^{\mathrm{b}}(\mathrm{wt} \% \mathrm{daf})^{\mathrm{c}}$ & 2.3 & 2.5 & 6.2 & 0.5 & 3.1 & 2.2 & 0.4 \\
\hline GCV (MJ/kg) & 38.6 & - & 33.4 & 38.6 & -. & 37.9 & 37.1 \\
\hline
\end{tabular}

${ }^{\dagger}$ granulated scrap tyres

${ }^{a}$ Contents on a dry basis $(\mathrm{db})$.

${ }^{\mathrm{b}}$ Calculated by difference.

${ }^{\mathrm{c}}$ Dry ash free basis (daf). 


\section{Table 2}

Main characteristics of the tyre-derived oil

\begin{tabular}{lccccc}
\hline & \multicolumn{5}{c}{ ThermolysisTemperature $\left({ }^{\circ} \mathrm{C}\right)$} \\
& 500 & 525 & 550 & 650 & 700 \\
& & & & & \\
\hline $\mathrm{C}$ (wt.\%) & 87.2 & 86.0 & 85.5 & 85.1 & 86.4 \\
$\mathrm{H}$ (wt.\%) & 11.4 & 11.1 & 10.7 & 9.0 & 9.4 \\
$\mathrm{~N}($ wt-\%) & 0.3 & 0.3 & 0.4 & 0.6 & 0.4 \\
$\mathrm{~S}$ (wt.\%) & 0.9 & 0.9 & 0.7 & 1.0 & 0.7 \\
$\mathrm{O}$ (wt.\%, by differ.) & 0.2 & 1.7 & 2.7 & 4.3 & 3.1 \\
$\mathrm{H} / \mathrm{C}$ atomic ratio & 1.56 & 1.55 & 1.50 & 1.27 & 1.30 \\
$\mathrm{GCV}(\mathrm{MJ} / \mathrm{kg})$ & 42.8 & 42.5 & 42.5 & 41.9 & 41.3 \\
Suspension solids, $(\% \mathrm{w} / \mathrm{w})$ & 0.25 & 0.18 & 0.1 & 0.15 & 0.09 \\
Density at $20{ }^{\circ} \mathrm{C},\left(\mathrm{kg} / \mathrm{m}^{3}\right)$ & 0.91 & 0.92 & 0.94 & 0.94 & 0.94 \\
Viscosity at $40^{\circ} \mathrm{C},(\mathrm{cSt})$ & 3.3 & 2.8 & 2.8 & 2.7 & 2.6 \\
Flash point, $\left({ }^{\circ} \mathrm{C}\right)$ & $<20$ & $<20$ & $<20$ & $<20$ & $<20$ \\
\hline
\end{tabular}




\section{Table 3}

Main components of the tyre-derived oils determined by CG-MS (\% area)

\begin{tabular}{|c|c|c|c|c|c|}
\hline \multirow[t]{2}{*}{ Compound } & \multicolumn{5}{|c|}{ Thermolysis temperatura $\left({ }^{\circ} \mathrm{C}\right)$} \\
\hline & 500 & 525 & 550 & 650 & 700 \\
\hline Anthracene and 1-methylanthracene & $<1.0$ & n.d $d^{\mathrm{a}}$ & n. $d^{\mathrm{a}}$ & 1.2 & $<1.0$ \\
\hline $\begin{array}{l}\text { Benzene and their derivates } \\
\text { (Ehtyl; Ehyl-Methyl; Propyl ; 1-Methyl-4-Propyl; } \\
\text { Tetramethyl; Trymethyl Benzene) }\end{array}$ & 26.6 & 22.7 & 22.9 & 25.8 & 24.6 \\
\hline Benzothiazole & 2.1 & 1.9 & 2.0 & 2.1 & 1.9 \\
\hline $\begin{array}{l}\text { Benzothiophene ; 2,3 - dimethylbenzothiophene ; } \\
\text { Dymethylthiophene }\end{array}$ & $<1.0$ & 2.2 & 1.2 & $<1.0$ & $<1.0$ \\
\hline $\begin{array}{l}\text { Biphenyl and derivates } \\
\text { (Methyl Biphenyl) }\end{array}$ & 2.4 & 0.9 & 2.0 & 3.3 & 2.1 \\
\hline 7-ethyl-1,4-dimethylazulene & 1.2 & 1.2 & n.d $\mathrm{d}^{\mathrm{a}}$ & n.d $\mathrm{d}^{\mathrm{a}}$ & n.d $\mathrm{d}^{\mathrm{a}}$ \\
\hline (1-methylethyl)benzene & 1.3 & 1.5 & 1.2 & $<1.0$ & $<1.0$ \\
\hline Cycle butane ; methyl and dimetyl-cycle hexene & 4.0 & 5.6 & 1.9 & 1.7 & 1.6 \\
\hline $\begin{array}{l}\text { Cycle pentane; n-pentadecane; n-heptadecane and } \\
\text { n-octane }\end{array}$ & 4.4 & 2.3 & 4.7 & 2.3 & 1.1 \\
\hline Dimethylquinoline & 1.1 & $\mathrm{n} . \mathrm{d}^{\mathrm{a}}$ & 0.9 & 1.1 & n.d $d^{\mathrm{a}}$ \\
\hline Fluorene and methylfluorene & $<1.0$ & $n \cdot d^{\mathrm{a}}$ & n. $\mathrm{d}^{\mathrm{a}}$ & 1.5 & 2.6 \\
\hline Indane and Methylindane & 1.1 & 2.2 & 1.0 & n.d $\mathrm{d}^{\mathrm{a}}$ & n.d $\mathrm{d}^{\mathrm{a}}$ \\
\hline $\begin{array}{l}\text { Indene and derivates } \\
\text { (Indene; Dimethylindene; } 1 \mathrm{H} \text {-indene ; Dimethyl- } \\
\text { 1H-indene; Dihidro dimethylindene) }\end{array}$ & 9.9 & 12.4 & 13.3 & 12.1 & 12.3 \\
\hline $\begin{array}{l}\text { 1-methyl-4-(1-methyletheyl)-ciclohexene (DL } \\
\text { Limonene) }\end{array}$ & 2.7 & 2.1 & 2.0 & 1.0 & $<1.0$ \\
\hline $\begin{array}{l}\text { Naphthalene and derivates } \\
\text { (Naphthalene; 1-Methyl ; 2- Methyl , Ethyl; } \\
\text { Dimethyl; Trimethyl; Tetramethyl Naphthalenes) }\end{array}$ & 10.8 & 12.0 & 16.6 & 19.8 & 18.8 \\
\hline Phenanthrene & 1.0 & $n \cdot d^{a}$ & n.d $d^{a}$ & n.d $\mathrm{d}^{\mathrm{a}}$ & $<1.0$ \\
\hline Phenol and derivates & 0.9 & $\mathrm{n} . \mathrm{d}^{\mathrm{a}}$ & n.d $d^{\mathrm{a}}$ & n.d $\mathrm{d}^{\mathrm{a}}$ & $<1.0$ \\
\hline Styrene and Methyl-styrene & 1.1 & 1.8 & 1.7 & 1.2 & 3.1 \\
\hline Toluene and 4-isopropyltoluene & 16.0 & 17.5 & 16.5 & 12.9 & 13.3 \\
\hline Xylene; o-xilene; m-xilene; p-xilene & 6.2 & 7.0 & 7.5 & 12.5 & 12.0 \\
\hline Non-identified compounds & 9.8 & 6.6 & 3.8 & 2.5 & 2.7 \\
\hline
\end{tabular}

${ }^{\mathrm{a}}$ Not detected 


\section{Table 4}

Composition (vol.\%) and main characteristics of the thermolysis gases and production of electricity at different thermolysis temperatures.

\begin{tabular}{cccccc}
\hline \multirow{2}{*}{ Gas } & \multicolumn{5}{c}{ Thermolysis temperature $\left({ }^{\mathbf{o}} \mathbf{C}\right)$} \\
\cline { 2 - 6 } & $\mathbf{5 0 0}$ & $\mathbf{5 2 5}$ & $\mathbf{5 5 0}$ & $\mathbf{6 5 0}$ & $\mathbf{7 0 0}$ \\
\hline $\mathrm{H}_{2}$ & 10.7 & 14.2 & 19.9 & 20.5 & 23.1 \\
$\mathrm{CO}_{\mathrm{x}}$ & 8.7 & 7.0 & 5.2 & 3.9 & 5.9 \\
$\mathrm{C} 1$ & 13.6 & 16.0 & 18.3 & 18.4 & 17.7 \\
$\mathrm{C} 2$ & 8.6 & 9.4 & 11.2 & 12.1 & 13.6 \\
$\mathrm{C} 3$ & 8.1 & 9.2 & 9.4 & 9.8 & 10.8 \\
$\mathrm{C} 4$ & 47.6 & 40.1 & 28.5 & 27.2 & 25.1 \\
$\mathrm{H}_{2} \mathrm{~S}$ & 0.8 & 0.8 & 0.9 & 0.8 & 0.9 \\
$\left(\mathrm{O}_{2}+\mathrm{N}_{2}\right)$ & 4.4 & 3.3 & 6.5 & 6.9 & 2.7 \\
$\mathrm{GCV}\left(\mathrm{MJ} / \mathrm{Nm}{ }^{3}\right)$ & 84.6 & 77.2 & 64.7 & 64.1 & 63.9 \\
$\mathrm{GCV}(\mathrm{MJ} / \mathrm{kg})$ & 46.1 & 45.7 & 45.1 & 45.7 & 45.1 \\
$\left.\mathrm{Density}(\mathrm{Kg} / \mathrm{Nm})^{3}\right)^{\mathrm{a}}$ & 1.78 & 1.64 & 1.40 & 1.64 & 1.40 \\
$\mathrm{Yg}\left(\mathrm{Nm}{ }^{3} / \mathrm{kgGST}\right)^{\mathrm{b}}$ & 0.46 & 0.56 & 0.65 & 0.66 & 0.67 \\
$\eta(\mathrm{kWh} / \mathrm{kgGST})^{\mathrm{a}}$ & 10.5 & 11.6 & 11.4 & 11.5 & 9.9 \\
$\zeta(\mathrm{kWh} / \mathrm{kgGST})^{\mathrm{b}}$ & 4.1 & 4.8 & 5.0 & 6.6 & 6.5 \\
$\mathrm{Re}(\%)$ & 39.3 & 41.9 & 43.9 & 57.5 & 58.9 \\
\hline
\end{tabular}

${ }^{a}$ Estimate theoretically (Based on the composition of the gas in weight \%).

${ }^{\mathrm{b}}$ Experimental data. 


\section{Table 5}

Sulphur in the solid (char) and tyre-derived oil (TDO) fractions

\begin{tabular}{ccccc}
\hline $\begin{array}{c}\text { Thermolysis } \\
\text { Temperature } \\
\left({ }^{\circ} \mathrm{C}\right)\end{array}$ & \multicolumn{2}{c}{$\begin{array}{c}\text { Solid } \\
\text { (char) }\end{array}$} & \multicolumn{3}{c}{$\begin{array}{c}\text { Liquid } \\
\text { (TDO) }\end{array}$} \\
\cline { 2 - 5 } & $\begin{array}{c}\text { S elemental } \\
\text { analysis (wt.\%) }\end{array}$ & $\begin{array}{c}\text { S solid/ S feed } \\
\text { (wt.\%) }\end{array}$ & $\begin{array}{c}\text { S elemental } \\
\text { analysis (wt.\%) }\end{array}$ & $\begin{array}{c}\text { S liquid/ S feed } \\
\text { (wt.\%) }\end{array}$ \\
\hline 500 & 2.4 & 52.0 & 0.9 & 23.0 \\
525 & 2.5 & 56.4 & 0.9 & 21.9 \\
550 & 2.5 & 56.3 & 0.7 & 16.6 \\
650 & 2.4 & 57.5 & 1.0 & 19.1 \\
700 & 2.3 & 58.7 & 0.7 & 13.3 \\
\hline
\end{tabular}




\section{Table 6}

Main characteristics of the chars.

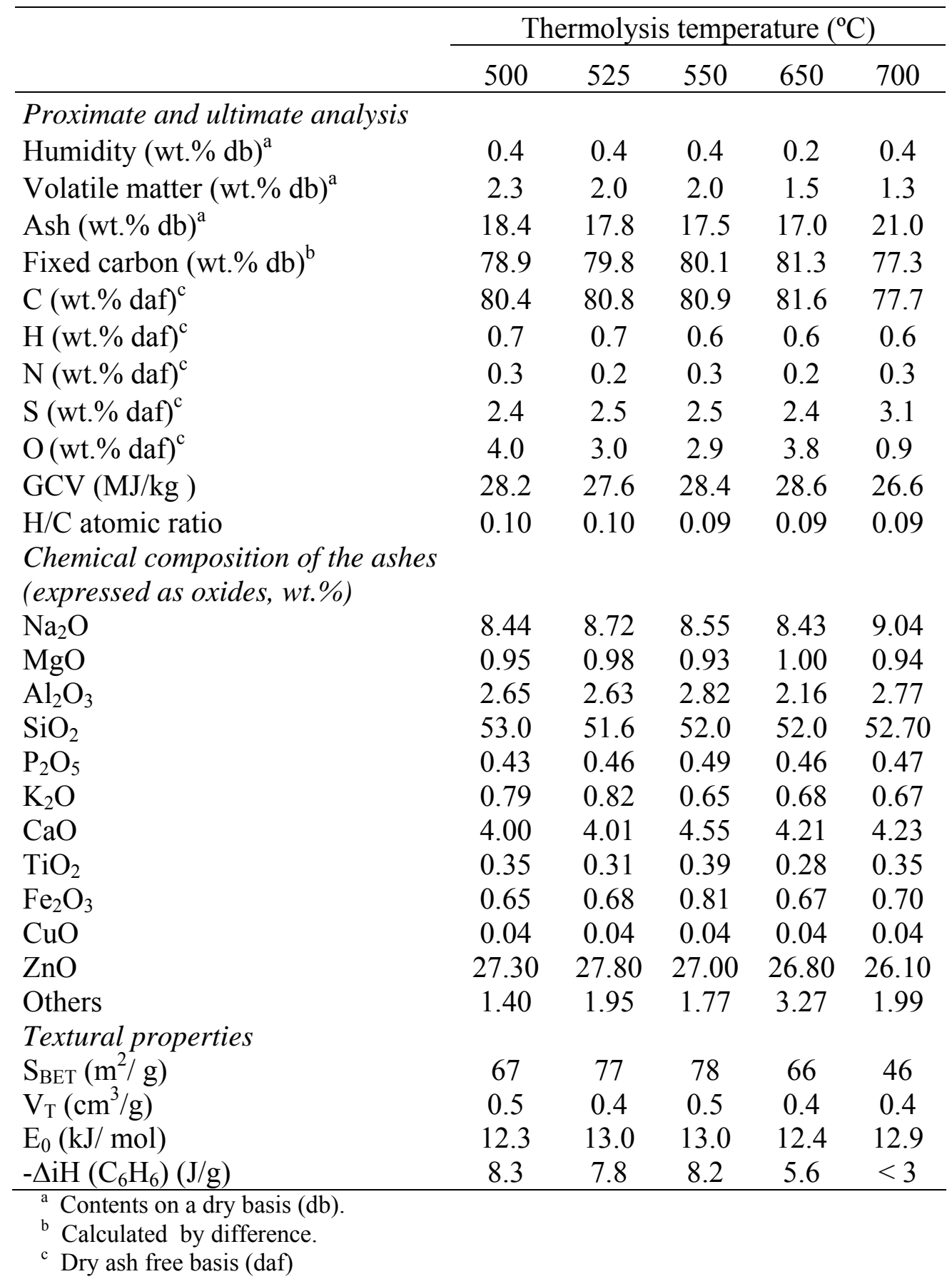


Table 7

Mass and energy balance

Mass Balance $\quad$ Energy Balance

$(\mathrm{kg} / \mathrm{T})$

$(\mathrm{MJ} / \mathrm{kg})$

Thermolysis temperature $\left({ }^{\circ} \mathrm{C}\right) \quad$ Thermolysis temperature $\left({ }^{\circ} \mathrm{C}\right)$

\begin{tabular}{|c|c|c|c|c|c|c|c|c|c|c|}
\hline & 500 & 525 & 550 & 600 & 700 & 500 & 525 & 550 & 600 & 700 \\
\hline \multicolumn{11}{|l|}{ Input } \\
\hline GST & 1000 & 1000 & 1000 & 1000 & 1000 & 38.6 & 38.6 & 38.6 & 38.6 & 38.6 \\
\hline Propane & 150 & 152 & 153 & 153 & 154 & 7.5 & 7.6 & 7.7 & 7.7 & 7.8 \\
\hline Total Input & 1150 & 1152 & 1153 & 1153 & 1154 & 46.1 & 46.2 & 46.3 & 46.3 & 46.4 \\
\hline \multicolumn{11}{|l|}{ Output } \\
\hline TDO & 460.3 & 438.1 & 425.8 & 352.1 & 343.1 & 19.7 & 18.6 & 18.1 & 14.8 & 14.2 \\
\hline Char & 389.7 & 406.1 & 406.9 & 431.3 & 443.1 & 11.0 & 11.2 & 11.6 & 12.3 & 11.8 \\
\hline Thermolysis Gases & 150.0 & 155.8 & 167.3 & 216.6 & 213.8 & 6.9 & 7.6 & 7.5 & 9.9 & 9.6 \\
\hline Total Output ${ }^{\mathrm{b}}$ & 1000 & 1000 & 1000 & 1000 & 1000 & 37.6 & 37.5 & 37.2 & 37.0 & 35.6 \\
\hline Energy Recovery $^{c}(\%)$ & & & & & & 81.6 & 81.2 & 80.3 & 79.9 & 76.9 \\
\hline
\end{tabular}

${ }^{a}$ Only the gases produced by the thermolytic process are considered since the propane was combusted in burners outside the reactor.

${ }^{\mathrm{b}}$ Mass balance refered to $1000 \mathrm{~kg}$ of GST.

${ }^{\mathrm{c}}$ Calculated from the equation: (Output Energy/Input Energy) * 100 